\title{
Effectiveness of Marital Couple Interventions on Marital Conflict: a Systematic Review and Meta-analysis of Experimental Studies
}

Likawunt Samuel Samuel ( $\nabla$ samuelliku@gmail.com )

Bahir Dar University College of Medical and Health Sciences https://orcid.org/0000-0003-4518-6067

\section{Getu Degu Alene}

Bahir Dar University College of Medical and Health Sciences

Research

Keywords: Marital interventions, systematic review, marital conflict, meta-analysis, Couple Therapy

Posted Date: February 16th, 2021

DOl: https://doi.org/10.21203/rs.3.rs-207900/v1

License: (c) (i) This work is licensed under a Creative Commons Attribution 4.0 International License. Read Full License 


\section{Abstract}

Background: Marital life is an important social institution that greatly influences the health and well-being of individuals and the entire society. Inherently, marriage is a complex phenomenon that the risks for marital instability are ubiquitous including social upheavals, stay home order due to Coronavirus Disease 2019 (COVID 19). Several studies have been proposed different interventions to optimize the quality of marital life. However, problems related to marital conflict are getting worse and there are uncertainties about the effectiveness of the interventions. Thus, the current systematic review was aimed at examining the effectiveness of interventions in reducing a variety of aspects of marital conflict among the cohort of married couples.

Methods: Randomized controlled trial (RCT) and Qazi experimental studies describing the effectiveness of marital couple interventions published over the last 10 years were retrieved from six electronic databases using different search terms, Medical subject heading (MeSH) terms "Marital therapy", "Couple therapy", or "Marital couple therapy" included in this study. The risk of bias in individual studies assessed based on the Cochrane Risk of Bias Tool. The effectiveness of the interventions was examined by comparing the intervention group with those who did not receive the intervention.

Results: A total of 14, 536 records are searched from 6 databases, and eleven of these studies are included in the final systematic review and meta-analysis. Overall, the included studies were identified to have a low risk of bias and a substantial level of heterogeneity $\left(I^{2}=96 \%\right)$. The meta-analysis confirmed that marital couple's interventions significantly improved marital conflict among distressed couples (Pooled effect size, $-1.71,[-2.93,-0.49]$ )

Conclusions: This finding indicated that marital couples' interventions effectively reduce marital conflict among a cohort of married couples. Thus, marital counselors and educators are strongly suggested to compile and use the interventions outline in this study.

Funding: There is no source of funding, that, the authors have no competing interests to declare.

Systematic review registration: This study is registered as PROSPERO: CRD42020218280

\section{Background}

Marital life is an important social institution that greatly influences the health and well-being of individuals and the entire society. In other words, marriage is a social construct in the form of a formal union of a man and a woman, typically recognized by law, by which they become husband and wife on a range of issues (1). Inherently, it is a complex phenomenon that the risks for marital instability are ubiquitous including social upheavals, stay home order due to Coronavirus Disease 2019 (COVID-19)(2).

There are many reasons why the grace given to us to live in peace and harmony can cause us to suffer from marital conflict and cause the problems mentioned above. Here are some of them: Individual partner's life course factors such as behavioral correlates and secret life courses, relational and communicational dynamics, knowledge and life skills and unnecessary involvement of significant others are the most cited reasons for marital conflict $(3,4)$.

Besides, substance use and secret life such as second relationships are the common behavioral correlates. Tobacco and marijuana use was also related to divorce through their associations with other variables. Substance use impacts marital status by engaging in sexual risk behavior like commencing sex with multiple partners, thus, individuals who engage in risky health behaviors are more likely to divorce than individuals who do not engage in these behaviors(5).

Weakened communications that lack transparency and social media misuse are also found to affect marital relationships. Regardless of its outstanding role in marital dissolution, only a few studies are published in this title. One study from Europe and Africa and showed that the way spouses use social networks negatively affected their marital life $(6,7)$.

In addition to the aforementioned social and behavioral reasons, the role of emerging and reemerging infectious diseases, such as COVID-19, on marital conflict is not insignificant. Recent research also illustrates that the nature and various indirect consequences of the COVID-19 pandemic results in marital conflict(2) (8). In all aspects, there are controversies in risks for marital conflict, for instance, marriage duration, and age-at-marriage might not be strong enough to predict marital conflict(9). 
Shreds of evidence claimed that poor quality marital life such as frequent marital conflicts results in numerous health, social and economic consequences. If left untreated, it can further lead to marital dissolution. This in turn results in marked and long-lasting difficulties including profoundly deleterious health, psychological, and socio-economic impacts on the involved couples, their children, and the entire society(10).

The existing pieces of evidence assert that experiencing marital hardship increases the risk of subsequent mental and physical health problems and increased the demand for health service use. Anxiety, depression, sleep problems, and personality disorders are commonly reported mental health problems of marital hardships, poor quality of marital life, and marriage dissolution. Concerning its effect on physical health, previous studies concluded that poor marital quality results in poor physical health predicting more physical symptoms, chronic health problems, and physical disability, and poorer perceived health(11).

Cardiovascular disorder risks, gastrointestinal problems, diabetes mellitus, and sexually transmitted diseases are commonly reported physical health problems. An increasing range of cardiovascular disorders risk (CVDs) including worsening diastolic blood pressure and acute myocardial infection (AMI), were commonly reported effects of marital quality on the cardiovascular system $(12,13)$. Moreover, issues surrounding marital stress results in physiological \& gastrointestinal problem such as gastritis, low appetite, sleep disturbance, chest pain, brain stroke, senseless, numbness and vulnerability to sexually transmitted disease like HIV AIDS(14).

Importantly, few experience stress, suicidal attempts, and other behaviors such as crying, anger, loss of self-worth, guilt feeling, blame, trauma, rejection, misunderstanding in interpersonal relations, and non-acceptance(15). The stress of a breakup has also been known to challenge the future life of the involved partners, their children, and the entire community. As a result, the comprehensive interventions considering the stated risks were found to be very important to alleviate its negative impacts. Several studies have been proposed different interventions to reduce marital conflict. Despite these efforts, marriage problems are widely spread all over the world. However, Problems related to marriage, for instance: conflicts and marital dissolution are getting worse and there are uncertainties about the effectiveness of the interventions. This implies the need to examine the effectiveness of the proposed interventions and offer abreast options. Thus, it is important to examine the effectiveness of the proposed interventions and offer abreast options to reduce marital conflict. The findings of this study will be an important input to marriage educators and counselors to incorporate the concepts of these interventions in their education to successfully reduce marital conflict among distressed couples.

\section{Methods}

\section{Protocol and Registration}

This Systematic Review and Meta-Analysis is Registered and is registered as PROSPERO: CRD42020218280

\section{Inclusion and exclusion criteria}

The married men and women or couples (heterosexual marriages), and those having no known history of chronic diseases, sexual and reproductive health problems. comprised the population for this review. Either training and /or counseling were the intervention in this review. That means studies that evaluate the effectiveness of training and/ or counseling intervention for reducing marital conflict were considered in this systematic review. The studies evaluate the effectiveness of interventions on the various forms of marital quality such as marital conflict and improve marital satisfaction were also included in this review. The primary outcome of the current systematic review is reducing marital conflict and the secondary output is marital satisfaction. The studies must have a comparison or control group.

Both Randomized trials and quasi-experimental studies with pretest-posttest and control group designs were included in this systematic review. The current systematic review considered studies those used tested tools to measure marital conflict and used outcome measures such as mean difference and standard mean the difference in marital conflict. Besides, studies that have been explicitly stated the intervention procedures and published over the past 10 years were included. This systematic rechew 
included studies published in the English language. This is because most of the countries that share the culture with Ethiopia publish their study in English.

On the contrary, studies on specific segments of society were excluded. In other words, Studies that include participants selected from health care workers, the army, and having a history of infertility were excluded. Similarly, studies that focused on men only or women only, and same-sex marriages were also excluded. The reason for their exclusion pertains to the generalizability of the findings. Those studies that had an intervention period of fewer than 2 weeks were also be excluded.

\section{Data sources}

Cochrane Library, PubMed, BioMed Central, Cumulative Index to Nursing and Allied Health (CINAHL), Google Scholar, and MEDLINE databases were used as a data source. An electronic search strategy was used for the listed databases. The general search was done in Google Scholar search engines and an advanced search was done using different databases listed above. Different Medical subject heading (MeSH) terms "Marital therapy", "Marital couples therapy", and "Marriage" was used to search articles. The MeSH entry terms: Couples Therapies, Therapy, Couples, Couple Therapy, Therapies, Couple, Therapy, Couple. Couples Therapy, psychotherapy are used to treat couples suffering from marital conflict.

\section{Study selection}

The Preferred Reporting Items for Systematic Reviews and Meta-Analyses (PRISMA) flow diagram was used to screen and select studies based on eligibility, and inclusion criteria. Each article was filtered based on the text available, (Free full text, Clinical) article attributes, (Trial, RCT), and publication dates (in the last 10 years). The selected studies were transferred to the Mendeley Desktop reference manager for citation. In every step study articles that did not align with the eligibility criteria were removed. In the search and selection process, and inclusion/exclusion criteria were set to generate references for candidate studies.

\section{Data items}

In the current systematic review and meta-analysis, the following list of data items was used; the characteristics of study participants, the nature and duration of the intervention, details of the Comparison/ control group, and the type of outcomes and their measurements. The study design, assessment method, sample size, description of the data collection tool, data regarding the tool validity, reliability, pilot testing, and statistical methods used.

\section{Data extraction or data collection process}

We used the JBI data extraction form for experimental and observational studies (Annex 1) to obtain the necessary information about study characteristics and findings from the included studies. The data items were tailored to the review questions to extract relevant data(16). The specific items extracted from the full-text articles include the journal name, author's name, country, year of publication, impact factor of the published journal, searching database, number of searching databases, type of included study, intervention, duration of intervention, the data collection instrument, primary outcome, and authors conclusion. The details of the study participant characteristics were extracted. The Rev Man 5.3 was used to extract and analyze data.

\section{Critical appraisal}

Two reviewers performed an independent critical appraisal of selected studies using the standardized critical appraisal checklists developed by $\mathrm{JBI}(16)$. Disagreements between reviewers were solved by consensus. The methodological quality of individual studies was assessed for randomization; blinding; research instrument and measurement, statistical analysis. The induvial studies were screen using predetermined eligibility and inclusion criteria to reduce selection bias. Studies having low quality in 
statistical models were excluded from quantitative analysis but included for narrative synthesis. In assessing the methodological quality of studies, each of the previous studies was assigned one of the three categories: "low risk," "unclear risk," or "high risk."

\section{Summary measures}

The Mantel-Haenszel statistical method is used for the current meta-analysis. We used a random effect statistical model to determine the effect size. Since the outcome is continuous data, the standardized mean difference was preferred to examine differences in outcomes between groups. The $95 \%$ confidence intervals (Cls) are used to declare statistical significance. The effect size (SMD) was calculated automatically in Review Manager 3.5, which divides the difference in mean outcomes between experimental and control groups and divides by the pooled standard deviation.

\section{Synthesis results}

The heterogeneity between-studies were assessed using the $\mathrm{I}^{2}$ and Chi-square and the corresponding P-value. A cut point of $\mathrm{I}^{2}$ greater than or equal to $50 \%$ combined with a corresponding $P$ value $(P<0.05)$ test was set as evidence of substantial heterogeneity. The decision to use a fixed or random-effects model depends on the observed. levels of heterogeneity. In the current systematic review and meta-analysis, there was statistically significant heterogeneity between studies $\left(I^{2}=96 \%, P<0.001\right)$. Thus, a random-effects model was applied.

\section{Results}

\section{Results of the Search}

A total of 14, 536 records are searched from 6 databases. From the stated records, 265 studies were retained after duplicates were excluded. studies did not address dimensions of marital conflict among married couples from the general public and those studies that addressed marital conflict among couples in selected segments of the community are excluded. Studies that examined the effect of the intervention before and after using pretest-posttest without a control group were also excluded. Following a full-text analysis of 148 study articles, 117 that appeared to be not relevant were excluded. The remaining 31 studies were assessed for eligibility and 20 were excluded and 11 (5 for qualitative synthesis(17-21) 6 for quantitative analysis (22-27) included in the final systematic review and meta-analysis. Details of characteristics of included studies and reason for exclusion depicted in tables below.

\section{Study characteristics}

Looking at the nature of included studies, almost all of them applied therapies that were of different types and contents, having different follow-up periods, focused on various aspects of marital conflict, and were made on selected individuals and used different scales to measure the outcomes. Although their names and meanings vary, conflicts in marriage induce disagreements, and dissatisfaction, etc. results in problems in health. Since social and economic crises of either marital conflict or marital distress are similar, we combined existing studies for meta-analysis.

As provided above, the current systematic review and meta-analysis included studies from different parts of the world. Specifically, most of the studies were from different corners of the world, including from Region of American two studies $(17,20)$, Eastern Mediterranean Region seven studies (18,19,22-24,26,27), Southeast Asian region (01 studies) (21). The included studies were published between January 1, 2010, December 31, 2020.

\section{Design}


Regarding the content and depth of the included studies, most of them were experimental studies with pretest-posttest and follow up with a waiting-list or no-treatment control group. Out of the 11 studies, 5 were Quasi-experimental studies, with Pretest Posttest and control group design(18,19,22,23,25), 4 were Qazi- experimental studies with pretest, post-test, control group and follow-up $(20,24,26,27), 1$ experimental study, with group A and Group B, compares two different interventions(17) and 1 Experimental study with Pre-Posttests, that compares the intervention before and after without control (21).

\section{Population}

There are perhaps various population attributes, sample involved, age, sex distribution, marital duration, and educational level were being described. Accordingly, participants from different socio-demographic characteristics were included in the current systematic review. A total of 911., people were surveyed, with an average number of 31 couples or 66 individuals were included in each study. When we look at the participants in each domain in detail, in Experimental arm Male=total 231, 7-43 and in average 21 individuals included in each study, Women total 231, 7-43 in average 21 individuals included in each study. Similarly, in the control arm, Male=total 225, 8-43, and on average 20 individuals included in each study, Women total 224, 8-42 in average 20 individuals included in each study. The mean age of the samples ranged from 21 to 71 years old and 72 have a minimum of high school diploma and higher $(22,24)$. Since the participants were couples, $50 \%$ identified as men and $50 \%$ were women

\section{Intervention}

The proposed interventions in the included studies comprised training and or counseling services that were tailored to the stated population using group counseling, verbal or written methods. The stated interventions were provided in a clinic or the community and targeted to men, women, or couples. But few studies did not specify where the intervention would be delivered (Bakhshandeh et al, 2015, Cornelius, Tara L.2007)(17,23).

Concerning the types of interventions, McMaster training model(22), Cognitive-behavioral group counseling and integrated Cognitive-behavioral therapy (ICBT), and Cognitive-behavioral therapy (CBT) intervention $(23,25)$ intimacy training with cognitivebehavioral approach(19), Gottman's couple therapy, Gottman et al. hypothesis that the speaker-listener technique couple discussing an issue about each other(17,24), Prevention and Relationship Education Program (PREP) training,(26), (PREP) or (CARE)(20), the conflict resolution skills training(27), Marital counseling on marital quality(21), and mindfulness training (18) were tested for their effect on different dimensions of marital conflict. Each of the above interventions consisted of three to ten gatherings, each lasting an average of 192.7 minutes. They had an average of two months of follow-up.

\section{Comparison}

The comparison can be done between the intervention under the study and another intervention, or usual care, or without any intervention. Seven (58.3\%) compared the effect of the interventions with those who did not receive the intervention in the control condition $(18,19,22-24,26,27)$. One study $(8.5 \%)$ compared CBT and CBT control treatment with a no-treatment control group (25). Two studies (16.7\%) $(20,21)$, compared marital counseling and PREP group intervention and its effect in similar population on marital quality before (Pretests) and after (Posttest) intervention. Conversely, one study (8.5\%) discussions on the emotionally charged issue within their marriage and outside their marriage(17).

\section{Outcome}

Marital conflict refers to an open or latent antagonism between marriage partners due to various reasons including, sexual disagreement, child-rearing differences, temperamental and, religious differences and disagreements over money management that could result in a lot of adverse conditions unless managed properly (1) was the primary outcome of the current study.

The studies described above have been conducted to examine the effectiveness of interventions on marital conflict. In other words, different dimensions of marital quality such as marital conflict, and mindfulness, anxiety marriage, marital satisfaction

Page 6/20 
and communication behaviors, marital violence, marital satisfaction, and communication behaviors were the primary outcome variable of the included studies. Two studies $(16.7 \%)(18,27)$ examined the effect of an intervention on marital conflict.

Another study focused on marital quality, measured using a marital quality scale which has an internal consistency of 0.91 and test-retest reliability of 0.83 . This scale measured the twelve dimensions of marital quality including affection, decision making, despair, dissolution potential, discontent, dominance, rejection, role function, satisfaction, self-disclosure, trust, and understanding each other(21). Similarly, (24) and (23) examined the intervention effect on Marital violence and anxiety marriage respectively. Almost all treatment outcomes were measured by validated scales.

\section{Risk of bias assessment}

The risk of bias in individual studies assessed based on the Cochrane Risk of Bias Tool (28). Eight of the eleven studies were determined to have an overall low risk of bias $(18-20,22-25,27)$ Figure 3 . The Risk of bias in included studies depicted in table 3 below presents the findings of risk of bias criteria, with green indicating low risk; yellow, unclear risk; and red, high risk of bias.

Because of the nature and techniques of the interventions, blinding of both participants and investigators was found to be cumbersome. Overall, the risk of bias across all studies included in this synthesis is expressed as a percentage provided in figure 2. As noted, we found that most of the included studies had a low risk of bias. In general, except for one, allocation concealment; more than $50 \%$ of the items had a low risk of bias. Overall, the graph shows that approximately $100 \%$ of studies posed a low risk of bias concerning detailing the method of randomization. In $54.55 \%$ of the studies, it was unclear if a method of allocation concealment was used. The $90.9 \%$ of included studies posed a low risk of bias concerning "selective reporting bias" and about $63.63 \%$ of studies posed a low risk of bias to blinding of outcome assessment bias.

\section{Results of individual studies}

Out of 11 studies, seven (63.6\%) examined the effect of intervention between the participants who received the intervention (experimental) and control (not received any intervention(18,19,22-24,26,27), 1 (9.1\%) tested similar intervention on some population before and after (21), another $2(18.2 \%)$ study tested two different intervention between two groups (Group A, Group B) $(17,20)$, and $1(9.1 \%)$ examined the effect of two treatments between two intervention and control group(25).

Of these studies, 8 (72.7\%) showed consistent differences favoring marital couple intervention over usual care (no intervention) $(18-20,22-24,26,27)$. Out of the remaining 3 studies, 1 (9.1\%) show no difference between groups(17), whereas $2(18.2 \%)$ showed mixed-effects $(21,25)$

Concerning the findings of individual studies, couples who received McMaster model training showed a greater increase in mindfulness and decreased marital conflicts than those who did not receive this training(22). The young male and female in marriage who have been chosen to be married in a marital couple intervention reported more improvement in marital distress (anxiety marriage) compared to their control counterparts(23). Similarly, Davoodvandi and his colleagues found that Gottman's couple therapy approach had positive effects on improving marital adjustment and couples' intimacy(24). Distressed marital couples in IBCT and CBT reported more improvement in conflict-related and violence-related marital distress, however, ICBT was found to be more effective than CBT(25).

Another study(26), which examined the effect of PREP training on marital conflict and marital satisfaction reported a significant positive outcome(26). The conflict resolution skills training intervention for distressed couples was more effective and significantly reduce marital conflict(27) but the speaker-listener technique intervention did not show a significant effect(17)

In one study (21), the marital counseling intervention was tested among previously and currently married couples who come for counseling sessions showed significant positive outcome that, those received marital counseling intervention revealed significant differences in most of the dimensions of marital quality, compared with the control group. A small-group intervention designed to teach engaged and newlywed couples in managing conflict and problem resolution (PREP) or skills in acceptance, support, and

Page $7 / 20$ 
empathy (CARE) indicated that Couples in the no-treatment condition dissolved their relationships at a higher rate (24\%) than couples completing PREP, CARE $(18,20)$, and (18) also tested the effects of mindfulness, emotion regulation, and intimacy training interventions on marital conflict and marital quality. Both of the studies reported a significant positive effect of the intervention on the outcome.

\section{Meta-analytic Findings}

Six of the eleven studies selected for this study were considered for meta-analysis. The remaining five(17-21) were not subject to meta-analysis because they did not provide the means, standard deviations, and test statistics for outcome assessments.

Overall, the current Meta-analyses that examine the effectiveness of marital couple intervention versus control were conducted to test three outcome groups including marital conflict, anxiety marriage, and marital distress. The scales used to measure the effect sizes combined in the meta-analyses were validated and the results were presented using the SMDs with $95 \% \mathrm{Cls}$. The summary of effect sizes and confidence limit of individual studies depicted in figure 3. The numbers with a minus (-) sign favor the intervention that, marital interventions effectively reduce a variety of aspects of marital conflict among samples of married couples who experienced marital stress. Conversely, the number with a plus $(+)$ sign denotes that the marital interventions benefit the control.

Six studies (Experimental $n=182$, Control $n=194$ ) examined the dimensions of marital distress(22-27). Three of these studies used the marital conflict scale,(decreased cooperation, decreased sexual relation, increased emotional reactions, increased attraction of children's support, increased individual relation with relatives, decrease in family relations with relatives of spouse and friends, separation of financial affairs, and decrease of effective relation) and additional scales, including ENRICH Questionnaire, a revised Marital Satisfaction Inventory, and Five-Facet Mindfulness Questionnaire scale(22,26,27). Two used the Marital distress scale or Marriage anxiety questionnaire, $(23,25)$ and the other study used Spanier Questionnaire and Walker and Thompson's Questionnaire(24). The stated interventions significantly influence marital conflict. The meta-analysis finding showed a significant overall effect (SMD, 95\% Cl) of marital couple's intervention favoring the experimental group $(-1.71,[-2.93$, $-0.49]$. The analysis also confirmed that substantial levels of heterogeneity between studies $\left(I^{2}=96 \%\right)$, thus further analysis was not carried out.

\section{Discussion}

A total of 11 studies were used to summarize the effectiveness of marital interventions in reducing a variety of aspects of marital conflict among the samples of married couples who experienced marital stress. Initially, qualitative syntheses were carried out based on the findings of 5 studies. The remaining 6 were meta-analyzed. When we compile selected studies for the metaanalysis, the type and content of interventions, the desired outcome and the metrics used to measure these outcomes were complex and varied. The findings of the meta-analysis, which was done by taking the stated differences into account, showed that the various interventions were effective and have the potential to reduce marital problems.

Consistently, both qualitative synthesis and quantitative meta-analysis findings demonstrate either or both of the marital couples training and counseling interventions reduced a variety of aspects of marital conflict. This means the marital couple's intervention that clearly outlined in the intervention section above had a significant effect in favoring the intervention group. Overall, this finding is consistent with previous studies that marital couple interventions significantly improve maritally (29-32).

To better understand this effect in-depth, we seem to understand two things, the behavioral correlates of marital discord, and the biological makeup of human beings. Previous research findings showed that the causes of marital discord were related to behavioral difficulties $(33,34)$. Meanwhile, the treatments proposed in the current systematic review and meta-analysis included educational training. It is also well-known and expected that when a man learns can distinguish good and bad/evil and can reduce incivility effects and reinforce positive behavior. More likely, the cumulative effect of these facts explains the stated effect that training and counseling services can reduce marital problems by adjusting the behavior of the couples. Concerning the effects of the specific intervention on marital conflict, although the offered interventions, McMaster training model, Gottman's

Page $8 / 20$ 
couple therapy, and Prevention and Relationship Education Program (PREP) training vary in type and content, both found to have a positive significant effect in reducing marital conflict among distressed couples. As we explore each, one counseling intervention has ten sessions and lasts from ninety to one hundred and twenty minutes. It was about adjusting the behavior of couples with marital conflict. This intervention was provided in a hospital, by people who were more knowledgeable in the profession. The scales used to determine marital conflict was comprehensive in content and validated. The analysis findings of this study indicated that training the McMaster model has increased mindfulness and decreased marital conflicts between the couples(22).

Gottman's couple therapy also significantly reduced different aspects of marital conflict. The couples included in this study trained this ten 45-minute session of Gottman's couple therapy that was s performed once a week for 90 minutes to improve marital adjustment. The study finding revealed that Gottman's couple therapy improved marital adjustment(24).

However, a study experimentally examined the speaker-listener technique of communication skill training based on the Gottman et al. hypothesis concluded no differences between the couples in intervention and control groups in marital adjustment(17). In this study, both couples trained the speaker-listener technique of communication. The script that was developed from the PREP communication manual was used throughout the speaker-listener technique training and tailored to reflect the couples' experimental assignment. Those assigned to group 1 discussed the marriage issues (finances, sex, annoyances of your partner), and those assigned to group 2 discussed difficulties with a mutual friend, work, or family members (outside of the marriage). After completing the discussion, they completed the marital adjustment test and the four horsemen questionnaires that had been administered at the beginning of the session(17). These methodological variations could more likely explain the observed differences.

Studies from different corners of the world including the USA, India, Tehran, and Africa were considered in this study. Participants having diverse demographic and socio-cultural backgrounds were studied in the current systematic review and meta-analysis. Participants, both employed and unemployed, Islam as well as Christians, couples in the age group 20-71 years took in the analysis. Overall, this study examined the effect of marital couple intervention with a couple experiencing a range of educational as well as economically diverse, and the findings are therefore generalizable to a variety of distressing marital couples.

Moreover, we focused on and considered published, peer-reviewed journal articles because this article was thought to be methodologically rigorous and result in a valid conclusion. That could assure the validity of the findings. Indeed, it is well-known that marriage and marital life have spiritual and social implications. Despite this fact, like any other institution, it is affected by various obstacles and that can be cured if receives the appropriate and scientifically robust interventions.

Participants inclusion and exclusion requirements for some studies for instance(19,24), allowed those having a minimum of high school diploma and Bachelor's degree and(22) are non-participatory and very structured that limit other participants, and impede generalizability of the findings. In some studies, participants' choice is also problematic. For example, one study selected participants in a way that were suited them(24). This can be detrimental to the quality of the findings. Notably, most of the included studies did not use blinding techniques. This could also introduce the risk of bias, and impact the findings. in the current review. Another limitation of this study is that the participants of included studies in systematic review consisted of couples with marital conflict, thus the findings of this study cannot be generalized to the couples in the general public.

\section{Conclusion}

Despite the stated limitations, the findings of the current systematic review and meta-analysis demonstrated that the marital couple interventions effectively reduce marital conflict among a cohort of married couples. Marital counselors and educators are recommended to compile and use the couple interventions outlined in this study to mitigate marital conflicts. Individuals and organizations working in the era of family health are also encouraged to include the interventions examined in this study. As described above: the existing marital couples' interventions are highly varied and fragmented and are designed for distressed couples only. Therefore, researchers are recommended to design comprehensive and summarized interventions that can be applied in a friendly manner for all couples. Furthermore, authors are recommended to follow standard reporting formats including a detailed description of study characteristics and information required for systematic review and meta-analysis.

Page $9 / 20$ 


\section{List Of Abbreviations}

CBT: Cognitive-behavioral therapy, Cl: Confidence Interval, CINAHL: Cumulative Index to Nursing and Allied Health, COVID 19: Coronavirus Disease 2019, ICBT: Cognitive-behavioral therapy, JBI: The Joanna Briggs Institute, MEDLINE: Medical Literature Analysis and Retrieval System Online, MeSH: Medical subject heading, PREP: Prevention and Relationship Education Program, PRISMA: Preferred Reporting Items for Systematic Reviews and Meta-Analyses, PROSPERO: Patient-Reported Outcomes, PubMed: Published Literature in Medline, RCT: Randomized control trial, SMD: Standard mean the difference

\section{Declarations}

\section{Ethical approval and consent to participate}

Not applicable

\section{Consent for publication}

Not applicable

\section{Availability of data and materials}

Data will be obtained from the corresponding author whenever required.

\section{Competing interests}

The authors declare that they have no competing interests.

\section{Funding}

No funding sources

\section{Author's contributions}

LSA: Conceived and designed the study idea, developed a proposal, organized the data collection tool, created a data entry template, interpreted findings, and wrote the manuscript. GDA: Supervised the entire study process.

\section{Acknowledgments}

I would like to express my sincere gratitude to those who stood alongside me during preparing this study. My heartfelt thanks go to Bahir Dar University, College of Medicine and Health Science, School of Public Health for giving me this chance. I thank the Hosanna College of Health Sciences for its administrative support. My sincere appreciation and gratitude also go to Professor Getu Degu Alene, my primary supervisor, for his excellent scientific guidance and tireless efforts to make this work a reality.

\section{References}

1. Gary R. VandenBos. Dictionary of Psychology. Second. Washington, DC: AMERICAN PSYCHOLOGICAL ASSOCIATION; 2007. $624 \mathrm{p}$.

2. Reizer A, Koslowsky M, Geffen L. Health Care for Women International Living in fear: The relationship between fear of COVID-19, distress, health, and marital satisfaction among Israeli women Living in fear: The relationship between fear of. Health Care Women Int [Internet]. 2020;0(0):1-21. Available from: https://doi.org/10.1080/07399332.2020.1829626

3. Leonard KE, Homish GG. First Four Years of Marriage. 2014;22(1):25-35.

4. Leonard KE, Smith PH, Homish GG. Concordant and discordant alcohol, tobacco, and marijuana use as predictors of marital dissolution. Psychol Addict Behav. 2014;28(3):780-9. 
5. Meyer JM, Percheski C. Health behaviors and union dissolution among parents of young children: Differences by marital status. PLoS One. 2017;12(8):1-15.

6. John M. C AUSES O F M MARITAL CONFLICTS I N C CHRISTIAN MARRIAGES I N D OMBOSHAVA A REA, M ASHONALAND EAST PROVINCE, ZIMBABWE. IIJHAS. 2016;1(2):59-73.

7. Betül Aydın, Serkan Volkan Sarı MŞ. The Effect of Social Networking on the Divorce Process *. Univers J Psychol. 2018;6(1):1-8.

8. Bachand LL, Caron SL. Ties that bind: A qualitative study of happy long-term marriages. Contemp Fam Ther. 2001;23(1):105-21.

9. UDOKA P. O., OSINOWO H.O. AAOFP. DEMOGRAPHIC CORRELATES OF MARITAL CONFLICT AMONG MARRIED INDIVIDUALS IN IBADAN METROPOLIS. AFRICAN J Psychol STUDY Soc ISSUES. 2019;22(2):157-65.

10. Umberson D, Williams K, Powers DA, Needham B. You Make Me Sick: Marital Quality and Health Over the Life Course. J Heal Soc Behav. 2011;47(1):1-16.

11. Kiecolt-Glaser JK WS. Lovesick: How Couples' Relationships Influence Health. Physiol Behav. 2017;176(3):139-48.

12. Brown TE. Marital Quality and Cardiovascular Risk in Women During the Menopausal Transition. 2017.

13. Bennett-Britton I, Teyhan A, Macleod J, Sattar N, Smith GD, Ben-Shlomo Y. Changes in marital quality over 6 years and its association with cardiovascular disease risk factors in men: Findings from the ALSPAC prospective cohort study. J Epidemiol Community Health. 2017;71(11):1094-100.

14. Khan MR, Behrend L, Adimora AA, Weir SS, Tisdale C, Wohl DA. Dissolution of Primary Intimate Relationships During Incarceration and Associations With Post-Release STI / HIV Risk Behavior in a Southeastern City. Sex Transm Dis January. 2011;38(1):43-7.

15. Theodore F. Robles, Richard B. Slatcher, Joseph M. Trombello MMM. Marital quality and health: A meta-analytic review. Psychol Bull. 2015;140(1):140-87.

16. Aromatic E MZ (Editors). JBI MANUAL FOR EVIDENCE SYNTHESIS. 2020.

17. Cornelius TL, Alessi G, Shorey RC. The Effectiveness of Communication Skills Training With Married Couples: Does the Issue Discussed Matter? Fam J. 2007;15(2):124-32.

18. Molajafar H, Sm M, Lotfi R, Ghasemnejad SM, Falah M. Comparing the effectiveness of mindfulness and emotion regulation training in the reduction of marital conflicts. J Med Life. 2015;8(2):111-6.

19. Pourmousa H, Mohammadifar MA, Pesand ST, Rezaei AM. The effectiveness of intimacy training with cognitive-behavioral approach on couples ' life quality and happiness. 2018;15(May).

20. Rogge RD, Cobb RJ, Lawrence E, Johnson MD, Bradbury TN. Is skills training necessary for the primary prevention of marital distress and dissolution? A 3-year experimental study of three interventions. J Consult Clin Psychol. 2013;81(6):949-61.

21. Siji MM, Rekha KS. Effectiveness of Marital Counselling on Marital Quality among Young Adults: A Pre-Post Intervention. Int J Humanit Soc Sci Interv. 2018;7(04):11-23.

22. Babakhani V. Effectiveness of training the McMaster model on mindfulness and marital conflicts of couples. Int Behav Sci. 2016;10(1):66-71.

23. Bakhshandeh M, Sedrposhan N, Zarei H. The Effectiveness of Cognitive-Behavioral Group Counseling to Reduce Anxiety, Marriage; Single People have to be Married in Esfahan City (2013- 2014 ). UCT J Soc Sci Humanit Res. 2015;3(01):11-5.

24. Davoodvandi M, Nejad SN, Farzad V. Examining the Effectiveness of Gottman Couple Therapy on Improving Marital Adjustment and Couples ' Intimacy. Iran J Psychiatry. 2018;13(2):135-41.

25. Doh Fia S. Efficacy of Integrative Behavioural Couples Therapy and Cognitive Behavioural Therapy in Reducing Conflict and Violence-Related Marital Distress. Eur Sci J ESJ. 2020;16(20):66-77.

26. Fallahchai R, Fallahi M, Ritchie LL. The Impact of PREP Training on Marital Conflicts Reduction: A Randomized Controlled Trial With Iranian Distressed Couples. J Couple Relatsh Ther [Internet]. 2017;16(1):61-76. Available from:

http://dx.doi.org/10.1080/15332691.2016.1238793

Page $11 / 20$ 
27. Keshavarzi S, Mani A, Soleimani S, Sharif F. The Effect of Conflict Resolution Training on Marital Satisfaction in Couples Referring to Counseling Centers in Shiraz, Southern Iran. Confl Resolut Train Marital Satisfy [Internet]. 2012;1(1):26-34. Available from: https://www.researchgate.net/publication/258117979

28. Farrah K, Young K, Tunis MC, Zhao L. Risk of bias tools in systematic reviews of health interventions: an analysis of PROSPERO-registered protocols. Syst Rev [Internet]. 2019;8(280):1-9. Available from: https://doi.org/10.1186/s13643-019$1172-8$

29. Bodenmann G, Charvoz L. Prevention of marital distress by enhancing the coping skills of couples: 1-year. Swiss J Psychol. 2001;(May 2014).

30. Hahlweg K, Markman HJ. Effectiveness of Behavioral Marital Therapy: Empirical Status of Behavioral Techniques in Preventing and Alleviating Marital Distress. J Consult Clin Psychol. 1988;56(3):440-7.

31. Markman HJ, Renick MJ, Floyd FJ, Stanley SM, Clements M, Markman HJ, et al. Preventing Marital Distress Through Communication and Conflict Management Training: A 4- and $5^{\wedge}$ ear Follow-Up. J Consult Clin Psychol. 1993;61(1):70-7.

32. Webb TL. Does Changing Behavioral Intentions Engender Behavior Change? A Meta-Analysis of the Experimental Evidence. Psychol Bull. 2006;132(2):249-68.

33. Asadi ZS, Sadeghi R, Taghdisi MH, Zamani-alavijeh F, Khoshdel AR, Sciences M. Sources, Outcomes, and Resolution of Conflicts in Marriage among Iranian women: A qualitative study. Electron Physician. 2016;8(3):2057-65.

34. Tolorunleke CA. Causes Of Marital Conflicts Amongst Couples in Nigeria: Implication for Counselling Psychologists. Procedia - Soc Behav Sci [Internet]. 2014; 140:21-6. Available from: http://dx.doi.org/10.1016/j.sbspro.2014.04.381

\section{Tables}

Table 1. Characteristics of Included Studies 


\begin{tabular}{|c|c|c|c|c|c|c|c|}
\hline Author, Year & Location & $\begin{array}{l}\text { Study } \\
\text { design }\end{array}$ & $\begin{array}{l}\text { Population (n- } \\
\text { sample size) }\end{array}$ & Intervention & Comparator & $\begin{array}{l}\text { Length } \\
\text { of } \\
\text { follow } \\
\text { up }\end{array}$ & Outcome \\
\hline $\begin{array}{l}\text { Babakhani et } \\
\text { al. } 2016\end{array}$ & Tehran & $\begin{array}{l}\text { Quasi- } \\
\text { experimental } \\
\text { design, } \\
\text { Pretest } \\
\text { Posttest } \\
\text { with the } \\
\text { control } \\
\text { group }\end{array}$ & $\begin{array}{l}\text { Couples who had } \\
\text { referred to Social } \\
\text { Work Clinic due to } \\
\text { marital conflicts } \\
\text { during } 2014 \text { (age } \\
\text { range of } 30-45 \text {, } \\
\text { marriage duration of } \\
7 \text { - } 20 \text { years, and } \\
\text { Bachelor's degree } \\
\text { and higher) ( } n=40 \text {, } \\
F=20, M=20)\end{array}$ & $\begin{array}{l}\text { McMaster } \\
\text { training } \\
\text { model, } 10 \\
\text { sessions } \\
\text { each } 90-120 \\
\text { minutes }\end{array}$ & $\begin{array}{l}\text { Not } \\
\text { received the } \\
\text { training }\end{array}$ & $\begin{array}{l}\text { 3- } \\
\text { month }\end{array}$ & $\begin{array}{l}\text { Marital } \\
\text { Conflict, } \\
\text { mindfulness }\end{array}$ \\
\hline $\begin{array}{l}\text { Bakhshandeh } \\
\text { et al, } 2015\end{array}$ & Tehran & $\begin{array}{l}\text { Quasi- } \\
\text { experimental } \\
\text { with the } \\
\text { pretest- } \\
\text { posttest } \\
\text { control } \\
\text { group. }\end{array}$ & $\begin{array}{l}\text { The young male and } \\
\text { female in marriage } \\
\text { age }(21 \text { to } 34 \text { years } \\
\text { old), }(n=76, \text { Test } 38, \\
F=19, M=19, \\
\text { Control=38, } F=19, \\
M=19)\end{array}$ & $\begin{array}{l}\text { Cognitive- } \\
\text { behavioral } \\
\text { group } \\
\text { counseling }\end{array}$ & $\begin{array}{l}\text { Not under } \\
\text { any training }\end{array}$ & $\begin{array}{l}12 \\
\text { months }\end{array}$ & $\begin{array}{l}\text { Anxiety } \\
\text { marriage } \\
\text { (marital } \\
\text { distress) }\end{array}$ \\
\hline $\begin{array}{l}\text { Davoodvandi, } \\
\text { Navabi } \\
\text { Nejad, } \\
\text { Farzad, } 2018\end{array}$ & Tehran & $\begin{array}{l}\text { A semi- } \\
\text { experimental } \\
\text { study with } \\
\text { pretest, post- } \\
\text { test, and } \\
\text { follow-up }\end{array}$ & $\begin{array}{l}\text { Couples having a } \\
\text { minimum of a high } \\
\text { school diploma, } \\
\text { having children of } \\
\text { school age, had a } \\
\text { low score in the } \\
\text { Spanier Dyadic } \\
\text { Adjustment Scale } \\
\text { and the Walker and } \\
\text { Thompson Intimacy } \\
\text { Scale } \\
\text { (n=16 couples ( } 32 \\
\text { individuals, }\end{array}$ & $\begin{array}{l}\text { Gottman's } \\
\text { couple } \\
\text { therapy, } 45- \\
\text { minute } 10 \\
\text { sessions } \\
\text { performed } \\
\text { once a week } \\
\text { for } 90 \\
\text { minutes }\end{array}$ & $\begin{array}{l}\text { Not } \\
\text { received } \\
\text { counseling }\end{array}$ & $\begin{array}{l}\text { 1- } \\
\text { month } \\
\text { follow- } \\
\text { up }\end{array}$ & $\begin{array}{l}\text { Reducing } \\
\text { Conflict and } \\
\text { Violence- } \\
\text { Related } \\
\text { Marital } \\
\text { Distress }\end{array}$ \\
\hline
\end{tabular}

Table 1. Continued 


\begin{tabular}{|c|c|c|c|c|c|c|c|}
\hline $\begin{array}{l}\text { Author, } \\
\text { Year }\end{array}$ & Location & Study design & $\begin{array}{l}\text { Population (n-sample } \\
\text { size) }\end{array}$ & Intervention & Comparator & $\begin{array}{l}\text { Length } \\
\text { of } \\
\text { follow } \\
\text { up }\end{array}$ & Outcome \\
\hline $\begin{array}{l}\text { Stephen } \\
\text { Doh Fia. } \\
2020\end{array}$ & Ghana & $\begin{array}{l}\text { A quasi- } \\
\text { experimental. } \\
\text { pre-test, post- } \\
\text { test control } \\
\text { group. }\end{array}$ & $\begin{array}{l}\text { The } 30 \text { couples legally } \\
\text { married, severely } \\
\text { distressed couples aged } \\
\text { between } 21 \text { to } 60 \text { years } \\
\text { and having scores } \\
\text { between } 366-600 \text { on a } \\
\text { marital distress scale. } 60 \\
\text { individuals (n=30 couples, } \\
10 \text { (CBT), } 10(\text { IBCT) and } \\
10 \text { (CONTROL) }\end{array}$ & $\begin{array}{l}\text { ICBT and } \\
\text { CBT } \\
\text { intervention. } \\
\text { CBT has } 3 \\
\text { sessions } \\
\text { that lasted } \\
\text { for } 3 \text { hours. } \\
\text { IBCT } \\
\text { comprised of } \\
3 \text { sessions } \\
\text { that lasted } \\
\text { for } 3 \text { hours. }\end{array}$ & $\begin{array}{l}\text { IBC, C BT, } \\
\text { test, and } \\
\text { control }\end{array}$ & - & $\begin{array}{l}\text { Marital } \\
\text { conflict } \\
\text { and } \\
\text { marital } \\
\text { violence. }\end{array}$ \\
\hline $\begin{array}{l}\text { Reza } \\
\text { Fallahchai, } \\
\text { Maryam } \\
\text { Fallahi \& } \\
\text { Lane L. } \\
\text { Ritchie, } \\
2017\end{array}$ & Tehran & $\begin{array}{l}\text { Experimental } \\
\text { with a } \\
\text { pretest, } \\
\text { posttest, and } \\
\text { follow-up } \\
\text { design, } \\
\text { including a } \\
\text { control group }\end{array}$ & $\begin{array}{l}166 \text { dissatisfied } \\
\text { heterosexual couples } \\
\text { mean age }=32.34 \text { years } \\
(\mathrm{SD}=5.88 \text { years), and } \\
\text { their average length of the } \\
\text { marriage at baseline was } \\
5 \text { years (SD }=2.63 \text { years), } \\
\text { educational levels, } 74.8 \% \\
\text { had an associate of arts } \\
\text { degree and the rest had a } \\
\text { high school, } 12.4 \% \\
\text { unemployed, and } 65.5 \% \\
\text { employed. ( }=80 \text { couples, } \\
160 \text { individuals, Test } 42 \text {, } \\
F=42, M=42, \text { Control } 38 \\
F=38, M=38 \text { individuals) }\end{array}$ & $\begin{array}{l}\text { Prevention } \\
\text { and } \\
\text { Relationship } \\
\text { Education } \\
\text { Program } \\
\text { (PREP) } \\
\text { training, } 10 \\
\text { sessions }\end{array}$ & $\begin{array}{l}\text { Did not } \\
\text { receive any } \\
\text { training }\end{array}$ & $\begin{array}{l}\text { 12- } \\
\text { months } \\
\text { follow- } \\
\text { up }\end{array}$ & $\begin{array}{l}\text { Marital } \\
\text { distress }\end{array}$ \\
\hline $\begin{array}{l}\text { Sharif F, } \\
\text { Soleimani } \\
\text { S, Mani A, } \\
\text { Keshavarzi } \\
\text { S. } 2013\end{array}$ & Tehran & $\begin{array}{l}\text { The } \\
\text { interventional } \\
\text { and clinical } \\
\text { trial, pretest, } \\
\text { posttest, } \\
\text { follow-up }\end{array}$ & $\begin{array}{l}\text { The participants. }(n=56 \\
\text { couples } 112 \text {, experimental } \\
(\mathrm{n}=25 \text { couples, mean age } \\
\text { women } 34.6( \pm 5.37) \text {, men } \\
37.51( \pm 4.62), \text { ) and } \\
\text { control }(\mathrm{n}=31 \text { couples, } \\
\text { mean age women } 33.51 \\
( \pm 4.58), \text { men } 37.51 \\
( \pm 4.62),\end{array}$ & $\begin{array}{l}\text { The conflict } \\
\text { resolution } \\
\text { skills } \\
\text { training, } 10 \\
\text { sessions } \\
\text { twice a week, } \\
\text { lasting for } \\
1.5 \text { hours. }\end{array}$ & $\begin{array}{l}\text { No received } \\
\text { training }\end{array}$ & $\begin{array}{l}1 \\
\text { month }\end{array}$ & $\begin{array}{l}\text { The level } \\
\text { of } \\
\text { conflict } \\
\text { and } \\
\text { marital }\end{array}$ \\
\hline
\end{tabular}

Table 1. Continued 


\begin{tabular}{|c|c|c|c|c|c|c|c|}
\hline $\begin{array}{l}\text { Author, } \\
\text { Year }\end{array}$ & Location & Study design & $\begin{array}{l}\text { Population (n- } \\
\text { sample size) }\end{array}$ & Intervention & Comparator & $\begin{array}{l}\text { Length } \\
\text { of } \\
\text { follow } \\
\text { up }\end{array}$ & Outcome \\
\hline $\begin{array}{l}\text { Cornelius, } \\
\text { Tara } \\
\text { L.2007 }\end{array}$ & USA & $\begin{array}{l}\text { Experimental } \\
\text { design, with } \\
\text { group A and } \\
\text { Group B }\end{array}$ & $\begin{array}{l}\text { Length of marriage } \\
18.25 \text { years }(S D= \\
14.08) \text {, age range } 23 \\
-71, \text { mean of } 44.88 \\
(S D=13.63) \text {. } \\
\text { income level } \\
\$ 60,000 \text { and } \\
\$ 70,000 \text {, first } \\
\text { marriage }(n=50 ; \\
83.3 \%) \text {, no of } \\
\text { children reported } 2 \text {, } \\
(n=30 \text {, Test, } M=15, \\
F=15 \text {, Control } M=15 \text {, } \\
F=15)\end{array}$ & $\begin{array}{l}\text { Gottman et } \\
\text { al. } \\
\text { hypothesis } \\
\text { that the } \\
\text { speaker- } \\
\text { listener } \\
\text { technique } \\
\text { couple } \\
\text { discussing } \\
\text { an issue } \\
\text { about each } \\
\text { other }\end{array}$ & $\begin{array}{l}\text { Group B } \\
\text { discussed } \\
\text { an } \\
\text { emotionally } \\
\text { charged }\end{array}$ & $\begin{array}{l}3 \text { and } 6 \\
\text { months } \\
\text { follow } \\
\text { up }\end{array}$ & $\begin{array}{l}\text { Marital } \\
\text { satisfaction } \\
\text { and } \\
\text { communication } \\
\text { behaviors }\end{array}$ \\
\hline $\begin{array}{l}\text { Siji. M.M } \\
\text { 1, Rekha. } \\
\text { K. S. } \\
2018\end{array}$ & India & $\begin{array}{l}\text { An } \\
\text { experimental } \\
\text { study with } \\
\text { Pre-Post } \\
\text { tests }\end{array}$ & $\begin{array}{l}\text { Distressed couples, } \\
\text { age } 20-45 y r s, ~ l i v e d \\
\text { with their husband } \\
\text { for a minimum of } 6 \\
\text { months and no } \\
\text { known history of the } \\
\text { disease, no habit of } \\
\text { alcohol drinking. The } \\
\text { participants }(\mathrm{N}=60) \\
\text { couples. }(\mathrm{n}=60 \\
\text { couples, } \mathrm{M}=60 \text {, } \\
\mathrm{F}=60)\end{array}$ & $\begin{array}{l}\text { Marital } \\
\text { counseling } \\
\text { on marital } \\
\text { quality done } \\
\text { at } 3 \text { stages - } \\
\text { Pretest }\end{array}$ & $\begin{array}{l}\text { Pretest } \\
\text { score } \\
\text { compared } \\
\text { with } \\
\text { Posttest }\end{array}$ & $\begin{array}{l}3-6 \\
\text { Months }\end{array}$ & $\begin{array}{l}\text { Marital Quality } \\
\text { assessed using } \\
\text { MQS }\end{array}$ \\
\hline $\begin{array}{l}\text { Rogge } \\
\text { RD, Cobb } \\
\text { RJ, } \\
\text { Lawrence } \\
\text { E, } \\
\text { Johnson } \\
\text { MD, } \\
\text { Bradbury } \\
\text { TN, 2013 }\end{array}$ & USA & $\begin{array}{l}\text { A 3-Year } \\
\text { Experimental } \\
\text { Study of } \\
\text { Three } \\
\text { Interventions }\end{array}$ & $\begin{array}{l}\text { Newlywed couples } \\
(\mathrm{N}=174) \text {, mean age } \\
\text { Men } 29.3 \text { (SD 4.8) } \\
\text { years, } 6 \% \text {, } \\
\text { unemployed. } \\
\text { Women mean age } \\
27.9 \text { (SD }=4.9), 16 \% \\
\text { unemployed. Over } \\
\text { half were Caucasian } \\
(55 \%), \text { with } 21 \% \\
\text { Latino, } 11 \% \text { Asian, } \\
5 \% \text { African } \\
\text { American, and } 8 \% \\
\text { other. }\end{array}$ & $\begin{array}{l}\text { 4-session, } \\
15 \text {-hr small- } \\
\text { group } \\
\text { intervention } \\
\text { (PREP) }\end{array}$ & $\begin{array}{l}\text { Couples } \\
\text { were } \\
\text { compared } \\
\text { to each } \\
\text { other }\end{array}$ & $\begin{array}{l}\text { A 3- } \\
\text { Year } \\
\text { follow- } \\
\text { up }\end{array}$ & $\begin{array}{l}\text { Conflict and } \\
\text { problem } \\
\text { resolution }\end{array}$ \\
\hline
\end{tabular}

Table 1. Continued 


\begin{tabular}{|c|c|c|c|c|c|c|c|c|}
\hline Author, Year & Location & Study design & $\begin{array}{l}\text { Population } \\
\text { (n-sample } \\
\text { size) }\end{array}$ & Intervention & & Comparator & $\begin{array}{l}\text { Length } \\
\text { of } \\
\text { follow } \\
\text { up }\end{array}$ & Outcome \\
\hline $\begin{array}{l}\text { Molajafar H, } \\
\text { Mousavi SM, } \\
\text { Lotfi R, } \\
\text { Seyedeh Falah } \\
\text { M, } 2015\end{array}$ & Tehran & $\begin{array}{l}\text { A quasi- } \\
\text { experimental } \\
\text { study with } \\
\text { pretest- } \\
\text { posttest }\end{array}$ & $\begin{array}{l}\text { The 45 } \\
\text { married } \\
\text { people } \\
\text { having } \\
\text { marital } \\
\text { problems } \\
\text { (experimental } \\
\text { (15, and } \\
\text { control (15 } \\
\text { participants), } \\
\text { average ages } \\
\text { mindfulness } \\
\text { training } \\
19.92 \text {, } \\
\text { emotion } \\
\text { training } \\
33.93 \text {, and } \\
\text { control } 30.73\end{array}$ & $\begin{array}{l}\text { A. } \\
\text { mindfulness } \\
\text { training } \\
\text { eight } 90- \\
\text { minutes } \\
\text { sessions of } \\
\text { mindfulness } \\
\text { training }\end{array}$ & \multicolumn{2}{|c|}{$\begin{array}{l}\text { Test groups were } \\
\text { compared to each } \\
\text { other }\end{array}$} & - & $\begin{array}{l}\text { Marital } \\
\text { conflict }\end{array}$ \\
\hline $\begin{array}{l}\text { Mohammadifar } \\
\text { et al. } 2018\end{array}$ & Tehran & $\begin{array}{l}\text { Semi } \\
\text { experimental, } \\
\text { pretest- } \\
\text { posttest and } \\
\text { follow up } \\
\text { with control }\end{array}$ & $\begin{array}{l}\text { The } 50 \\
\text { couples aged } \\
20-27 \text { years, } \\
\text { having at } \\
\text { least a } \\
\text { diploma, no } \\
\text { serious } \\
\text { physical or } \\
\text { mental } \\
\text { illness. }\end{array}$ & \multicolumn{2}{|c|}{$\begin{array}{l}10 \text { sessions, } 45 \\
\text { minutes of intimacy } \\
\text { training with a } \\
\text { cognitive- } \\
\text { behavioral } \\
\text { approach }\end{array}$} & $\begin{array}{l}\text { Test group } \\
\text { compared } \\
\text { with control }\end{array}$ & - & $\begin{array}{l}\text { Couples' } \\
\text { quality of } \\
\text { life and } \\
\text { happiness. }\end{array}$ \\
\hline
\end{tabular}

NA. IBCT-Integrative Behavioral Couples Therapy, CBT-Cognitive Behavioral Therapy, PREP: Prevention and Relationship Education Program

Table 2. Summary of excluded studies with reasons for exclusion 


\begin{tabular}{|c|c|c|c|}
\hline S/No & Study & Title & Reason for exclusion \\
\hline 1. & Lisa A Benson & $\begin{array}{l}\text { The impact of behavioral couple therapy on attachment in } \\
\text { distressed couples }\end{array}$ & $\begin{array}{l}\text { Compares changes in } \\
\text { satisfaction to changes in } \\
\text { attachment }\end{array}$ \\
\hline 2. & $\begin{array}{l}\text { SM Ahmadi et } \\
\text { al, } 2019\end{array}$ & $\begin{array}{l}\text { The Effect of Behavioral Couple Therapy on the Improvement of } \\
\text { Mental Health and Reduction of Marital Conflict in Infertile } \\
\text { Couples in Kermanshah: (RCT) }\end{array}$ & $\begin{array}{l}\text { Among selected segments of } \\
\text { the population (Infertile } \\
\text { Couples) Population }\end{array}$ \\
\hline 3. & $\begin{array}{l}\text { Yektatalab S, et } \\
\text { al. } 2017\end{array}$ & $\begin{array}{l}\text { Efficacy of Bowen Theory on Marital Conflict in the Family } \\
\text { Nursing Practice: A Randomized Controlled Trial. }\end{array}$ & $\begin{array}{l}\text { couples referring to the } \\
\text { family court Population }\end{array}$ \\
\hline 4. & $\begin{array}{l}\text { Benson LA, } \\
\text { A. } 2013\end{array}$ & $\begin{array}{l}\text { The impact of behavioral couple therapy on attachment in } \\
\text { distressed couples }\end{array}$ & $\begin{array}{l}\text { Outcome attachment } \\
\text { Outcome }\end{array}$ \\
\hline 5. & $\begin{array}{l}\text { Ahluwalia } \\
\mathrm{H}_{, .} .2018\end{array}$ & Marital and family therapy. & $\begin{array}{l}\text { Reducing the severity of } \\
\text { substance use Outcome }\end{array}$ \\
\hline 6. & $\begin{array}{l}\text { Masoumi SZ, } \\
\text { Khani S, } \\
\text { Kazemi et al. } \\
2017\end{array}$ & $\begin{array}{l}\text { Effect of Marital Relationship Enrichment Program on Marital } \\
\text { Satisfaction, Marital Intimacy, and Sexual Satisfaction of } \\
\text { Infertile Couples. }\end{array}$ & Infertile Couples. Outcome \\
\hline 7. & $\begin{array}{l}\text { Gottman JM, } \\
\text { Tabares A. } \\
2018\end{array}$ & The Effects of Briefly Interrupting Marital Conflict. & The intervention is short \\
\hline 8. & $\begin{array}{l}\text { Schumm JA, } \\
\text { O'Farrell TJ, } \\
\text { Murphy MM, } \\
\text { P.2019 }\end{array}$ & $\begin{array}{l}\text { Efficacy of Behavioral Couples Therapy Versus Individual } \\
\text { Recovery Counseling for Addressing Posttraumatic Stress } \\
\text { Disorder Among Women with Drug Use Disorders. }\end{array}$ & $\begin{array}{l}\text { Among Women with Drug } \\
\text { Use Disorders. }\end{array}$ \\
\hline 9. & $\begin{array}{l}\text { Delatorre, M. Z. } \\
\text { \& Wagner } 2018\end{array}$ & Marital Conflict Management of Married Men and Women & $\begin{array}{l}\text { Compares the effect of two } \\
\text { interventions among married } \\
\text { or cohabiting couples }\end{array}$ \\
\hline \multirow[t]{2}{*}{10.} & \multirow{2}{*}{$\begin{array}{l}\text { Ebrahimi L, } \\
2018\end{array}$} & The Effectiveness of Human Validation Process & \multirow[t]{2}{*}{ The outcome is not related } \\
\hline & & Model Training on Couples' Marital Satisfaction & \\
\hline 11. & $\begin{array}{l}\text { Alipour et al., } \\
2020\end{array}$ & $\begin{array}{l}\text { Marital communication skills training to promote marital } \\
\text { satisfaction and psychological health during pregnancy: a } \\
\text { couple of focused approach }\end{array}$ & $\begin{array}{l}\text { Marital satisfaction and } \\
\text { psychological health during } \\
\text { pregnancy outcome }\end{array}$ \\
\hline 12. & $\begin{array}{l}\text { Keyhandoost, } \\
\text { M.2017 }\end{array}$ & $\begin{array}{l}\text { A Psychological Study on the Effectiveness of Marriage } \\
\text { Enrichment Training through PAIRS The method in Marital } \\
\text { Conflicts }\end{array}$ & Among women students \\
\hline 13. & $\begin{array}{l}\text { Beatrice } \\
\text { Umubyeyi, } 2019\end{array}$ & $\begin{array}{l}\text { Approaches to Marital Conflict Resolution: A Perspective of } \\
\text { Democratic Republic of Congo Migrants Living in Durban, South } \\
\text { Africa }\end{array}$ & Among migrants \\
\hline 14. & $\begin{array}{l}\text { Engl J.a } \\
\text { Thurmaier F.a } \\
\text { Hahlweg K.b } \\
2019\end{array}$ & Prevention of Divorce: Results of a 25-Year Follow-Up Study & Among premarital couples \\
\hline 15. & $\begin{array}{l}\text { Jahanshir T. } \\
2015\end{array}$ & $\begin{array}{l}\text { The Effectiveness of Communication Skills Training on Marital } \\
\text { Conflicts and its Different Aspects in Women }\end{array}$ & Considered only women \\
\hline 16. & $\begin{array}{l}\text { Mozhgan } \\
\text { RafieeHossein } \\
\text { Davoodi } 2016\end{array}$ & $\begin{array}{l}\text { Effectiveness of Educational Combination of Marital Relation } \\
\text { on Reducing Conflict Marital and Improvement of the Quality of } \\
\text { Life for Women }\end{array}$ & Considered only women \\
\hline 17. & $\begin{array}{l}\text { Maryam S. } \\
\text { Zadeh } 2020\end{array}$ & $\begin{array}{l}\text { The Effect of Communication Skills Training and Conflict } \\
\text { Resolution Tactics on Marital Satisfaction of Married Women in } \\
\text { Kermanshah }\end{array}$ & Considered only women \\
\hline 18. & $\begin{array}{l}\text { Donald H. } \\
\text { Baucom } 1998\end{array}$ & $\begin{array}{l}\text { Empirically Supported Couple and Family Interventions for } \\
\text { Marital }\end{array}$ & Year of publication \\
\hline
\end{tabular}


19. Allen et al. 2012 The Effects of Marriage Education for Army Couples with a History of Infidelity

20. Parvizian et al. 2015
The Effectiveness of Emotional Intelligence Training on Marital Satisfaction of Married Teachers Women in City of Yasuj
Army Couples with a

History of Infidelity

Among a selected segment of the community (teachers and women)

Table 3. Risk of bias summary, review authors judgments about each risk of bias item for each included study

\begin{tabular}{|c|c|c|c|c|c|c|c|c|}
\hline & 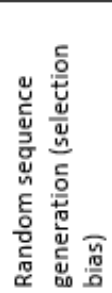 & 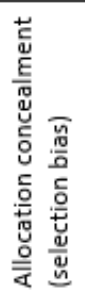 & 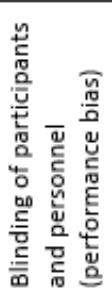 & 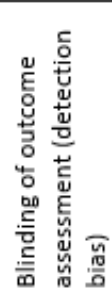 & 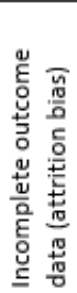 & 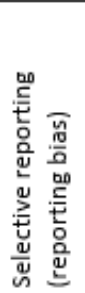 & 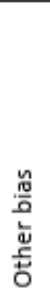 & 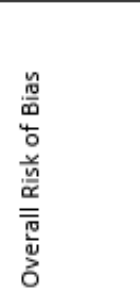 \\
\hline Babakhani et al. 2016 & & & & & & & & Low \\
\hline $\begin{array}{l}\text { Bakhshandeh et al, } \\
2015\end{array}$ & & & & & & & & Low \\
\hline $\begin{array}{l}\text { Davoodvandi, Navabi } \\
\text { Nejad, Farzad, } 2018\end{array}$ & & & & & & & & low \\
\hline Stephen Doh Fia. 2020 & & & & & & & & Low \\
\hline $\begin{array}{l}\text { R. FALLAHCHAI ET AL, } \\
2017\end{array}$ & & & & & & & & Moderate \\
\hline $\begin{array}{l}\text { Sharif F, Soleimani S, } \\
\text { Mani A, Keshavarzi S. } \\
2013\end{array}$ & & & & & & & & Low \\
\hline Cornelius, Tara L.2007 & & & & & & & & Moderate \\
\hline $\begin{array}{l}\text { Siji. M.M, Rekha. K. S. } \\
2018\end{array}$ & & & & & & & & High \\
\hline $\begin{array}{l}\text { Rogge RD, Cobb RJ, } \\
\text { Lawrence E, Johnson, } \\
\text { Bradbury TN, } 2013\end{array}$ & & & & & & & & Low \\
\hline $\begin{array}{l}\text { Molajafar H, Mousavi } \\
\text { SM, Lotfi R, Seyedeh } \\
\text { Falah M, } 2015\end{array}$ & & & & & & & & Low \\
\hline $\begin{array}{l}\text { Hossein P., } \\
\text { Mohammad Ali M., } \\
\text { Siavash Tale P. } 2018\end{array}$ & & & & & & & & Low \\
\hline
\end{tabular}

\section{Figures}




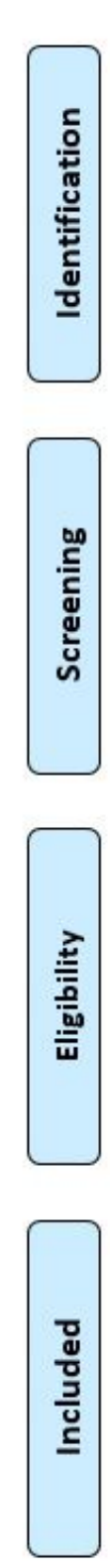

- Google scholar $(n=260)$

- PubMed $(n=2,179)$

- $\operatorname{PMC}(n=9,928)$

- NLM Catalog $(n=815)$

- ClinicalTrials.gov $(n=13)$
Additional records identified through other sources

$$
(n=1,341)
$$

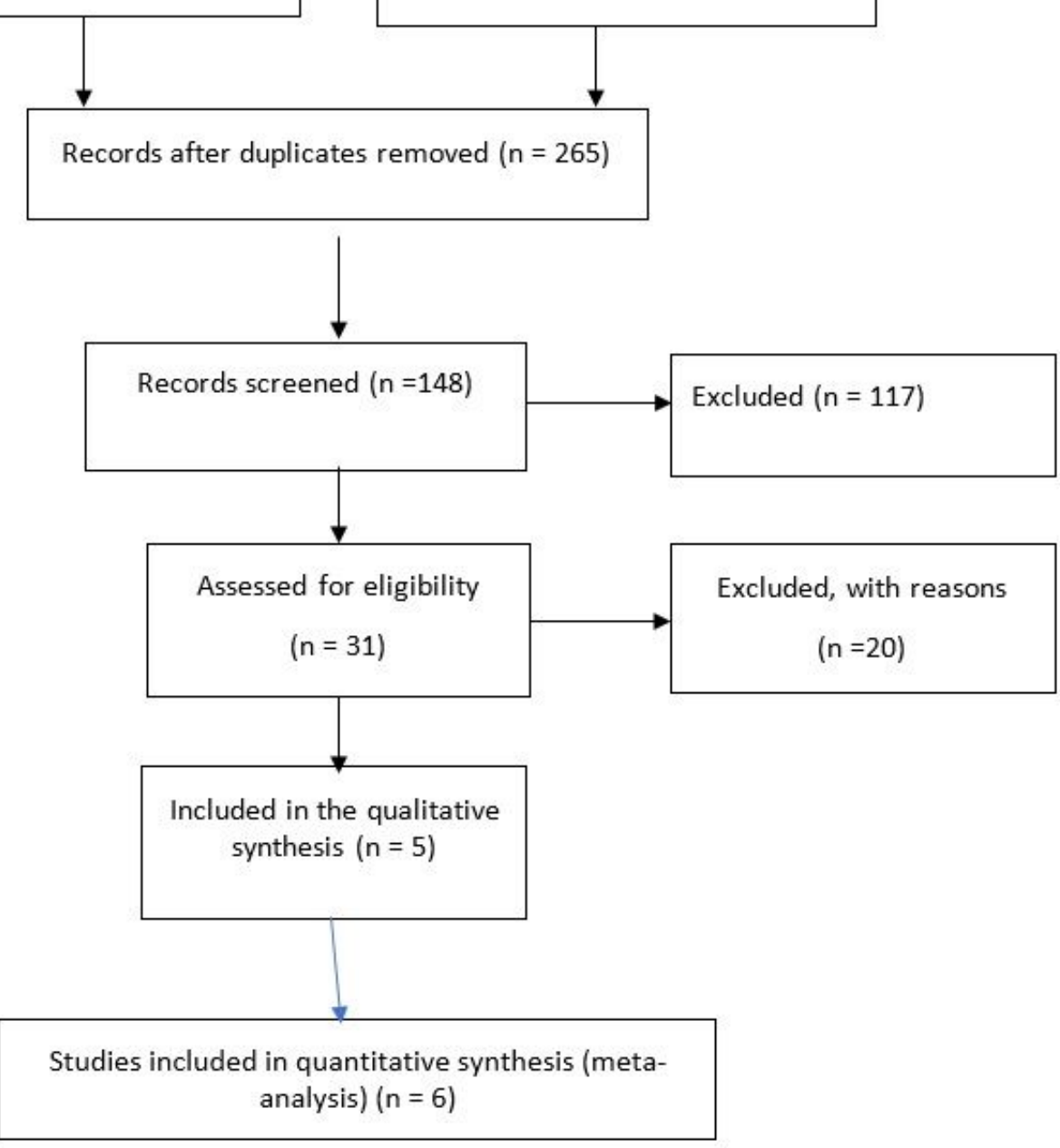

Figure 1

PRISMA flow chart depicting the screening and selection process of an article for a study entitled effectiveness of the marital intervention on the marital conflict that was undertaken as part of the systematic review 


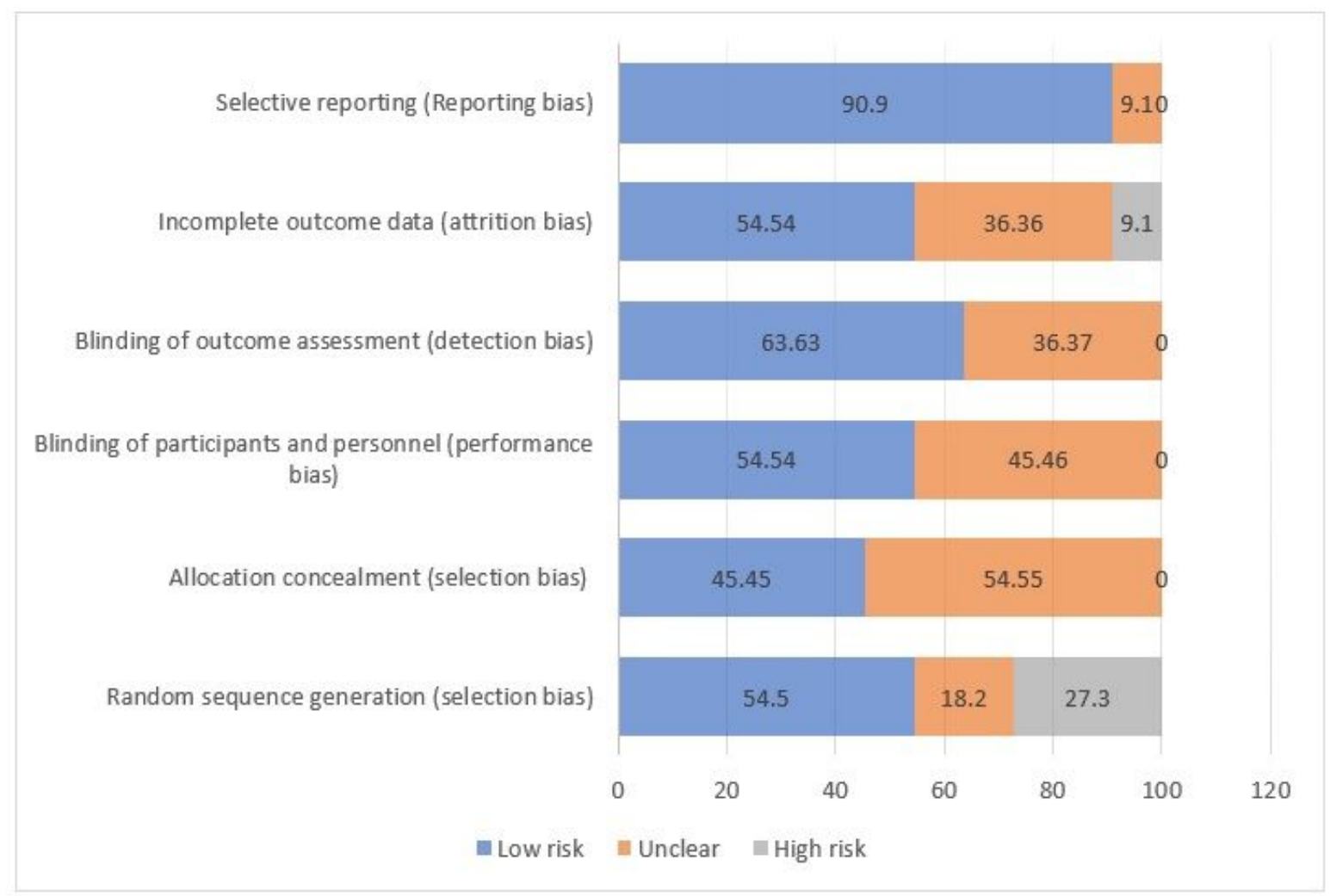

\section{Figure 2}

Risk of bias summary, review authors judgments about each risk of bias item for each included study by percent

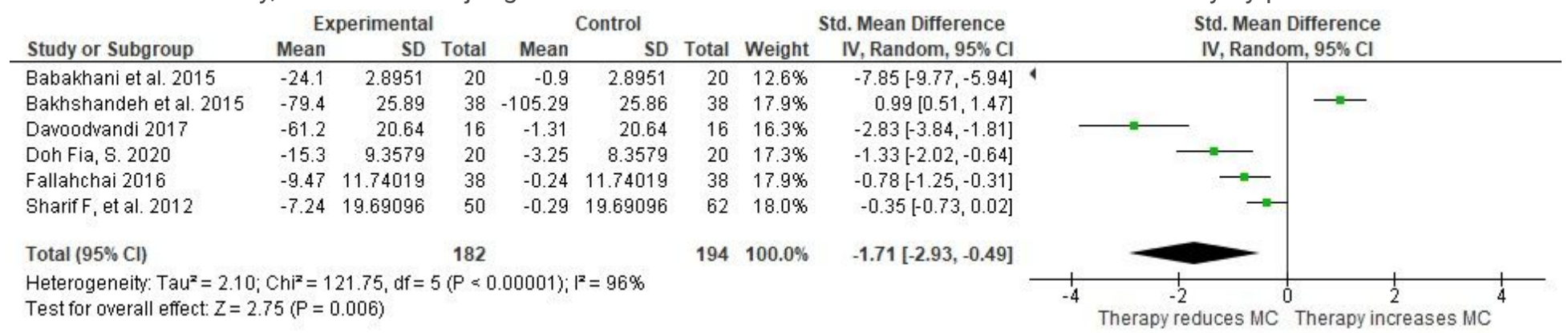

\section{Figure 3}

Forest plot examines the effectiveness of marital couple therapy on levels of marital conflict 